University of Michigan Law School

University of Michigan Law School Scholarship Repository

Law \& Economics Working Papers

$4-15-2020$

\title{
Taxation and Business: The Human Rights Dimension of Corporate Tax Practices
}

\author{
Reuven S. Avi-Yonah \\ University of Michigan Law School, aviyonah@umich.edu
}

Follow this and additional works at: https://repository.law.umich.edu/law_econ_current

Digipairt of the Human Rights Law Commons, Law and Economics Commons, Public Law and Legal

Fpermonsmmons, and the Tax Law Commons

Network

Logo

Working Paper Citation

Avi-Yonah, Reuven S., "Taxation and Business: The Human Rights Dimension of Corporate Tax Practices" (2020). Law \& Economics Working Papers. 173.

https://repository.law.umich.edu/law_econ_current/173

This Article is brought to you for free and open access by University of Michigan Law School Scholarship Repository. It has been accepted for inclusion in Law \& Economics Working Papers by an authorized administrator of University of Michigan Law School Scholarship Repository. For more information, please contact mlaw.repository@umich.edu. 


\title{
Taxation and Business: \\ The Human Rights Dimension of Corporate Tax Practices
}

\author{
Reuven Avi-Yonah \\ The University of Michigan
}

\section{Introduction: Human Rights and Taxation. ${ }^{1}$}

The current coronavirus pandemic highlights the need to address one of the most important social problems facing humanity at the beginning of the 21st century, which is the yawning divide in standards of living between the rich nations of the North and the poor nations of the South. The majority of the population in most developing countries live on less than \$2 a day. In some developing countries over a quarter of children aged 10-14 are employed in the work force. Mortality for children under five in developing countries can be ten to fifteen times as high as in developed countries. Over half the population in many developing countries lack access to safe drinking water or sanitation. Illiteracy rates among 15-24 year olds in developing countries can be as high as $40 \%$ for males and $60 \%$ for females. All of these gaps are even more troubling in the face of a global crisis like the coronavirus pandemic, as well as other problems like global climate change.

The persistence of such gaps is unacceptable. The North-South divide lies at the heart of the rich world's current troubles, including the threats of terrorism, immigration pressures, and environmental threats (such as global climate change), and the coronavirus pandemic. None of these issues can be adequately addressed without taking measures to bridge the divide, and to bring the South up to a level when it can cooperate with the North.

An agenda to begin bridging the divide already exists. The Sustainable Development Goals (SDGs) are a collection of 17 global goals designed to be a "blueprint to achieve a better and more sustainable future for all" .The SDGs, set in 2015 by a unanimous vote of the UN General Assembly and intended to be achieved by the year 2030, are part of UN Resolution 70/1, the 2030 Agenda. $^{2}$

The Sustainable Development Goals are:

1. No Poverty

2. Zero Hunger

3. Good Health and Well-being

\footnotetext{
${ }^{1}$ The first two parts of this chapter are a revised and updated version of Avi-Yonah, Bridging the North-South Divide: International Redistribution and Tax Competition, 26 Mich. J. Int'I L. 371 (2004).

2 United Nations (2019). https://sustainabledevelopment.un.org/?menu=1300.
} 

4. Quality Education
5. Gender Equality
6. Clean Water and Sanitation
7. Affordable and Clean Energy
8. Decent Work and Economic Growth
9. Industry, Innovation, and Infrastructure
10. Reducing Inequality
11. Sustainable Cities and Communities
12. Responsible Consumption and Production
13. Climate Action
14. Life Below Water
15. Life On Land
16. Peace, Justice, and Strong Institutions
17. Partnerships for the Goals

The key problem in achieving the SDGs by 2030 is the reluctance of people in the rich democracies to support foreign aid. Most of the rich countries provide less than $1 \%$ of their total budget to aid poor countries, and many (including the US) provide much less. Moreover, even this meager aid is highly unpopular: most opinion surveys in the US show that Americans both overestimate by a factor of over 100 how much aid is given, and would favor eliminating all foreign aid. In addition, most of the aid that is given is governed by political considerations rather than by where it would produce the best results (for example, a very high percentage of total US aid is given to Israel and Egypt under the 1977 Camp David accords).

It is possible to argue that given the link between the North-South divide and problems facing the North, such as terrorism and immigration pressures, it is shortsighted for the people of the North to oppose foreign aid. But there are four arguments to the contrary:

First, that even achieving the SDGs will not bridge the divide, so that the problems will persist. To really bridge the divide would require an unacceptable level of redistribution: Joel Slemrod and his colleagues have estimated that to achieve the same level of redistribution internationally as is currently achieved by the US tax system domestically, over $60 \%$ of the world's population would be on welfare, and tax rates on the remaining $40 \%$ would more than triple. $^{3}$

Second, the notion that "the poor of your own community come first" has a very strong hold, and most people are likely to continue supporting local causes before they support aid to foreigners.

\footnotetext{
${ }^{3}$ Wojciech Kopczuk, Joel Slemrod and Shlomo Yitzhaki, Why World Redistribution Fails (September 2002). NBER Working Paper No. w9186. Available at SSRN: https://ssrn.com/abstract=330325.
} 
Third, there is the concern that foreign aid is simply wasted, or worse, goes to the pockets of corrupt foreign officials. In the absence of adequate international supervision on aid distribution, this is a difficult argument to counter.

Finally, even if people are misguided in their opposition to foreign aid, in a democracy the people govern and their wishes should dictate the use of their tax money, rather than the wishes of the elite.

Thus, an increase in official aid to the level required by the SDGs is not in the cards. For the same reason, proposals to levy some kind of tax on the North in order to fund development in the South, like the Tobin Tax on currency exchanges or a tax on computer bits seem unlikely to be implemented, since voters in the North would not approve of them if brought before them, for the same reasons they disapprove of foreign aid.

Can anything be done, nevertheless, to help the South achieve the SDGs? It seems to me that the key is to help the developing countries help themselves, and the key to that is to identify issues in which opposition between the North and the South stems more from the influence of "special interests" in the North than from opposition by the people of the North as a whole. That is, the key is to identify issues on which the pro-development position would prevail if brought to a democratic vote in the North. One good example of such an issue seems to be trade in agricultural goods and textiles, in which the majority in rich countries would benefit if tariff barriers and subsidies were reduced.

Another issue like that is tax competition among developing countries, which costs them significant tax revenues, to benefit rich country interests like multinational enterprises and the financial services sector. To understand this issue requires an overview of current developments in international taxation as it relates to globalization.

In general, the current age of globalization can be distinguished from the previous one (from 1870 to 1914) by the much higher mobility of capital than labor (in the previous age, before immigration restrictions, labor was at least as mobile as capital). This increased mobility has been the result of technological changes (the ability to move funds electronically), and the relaxation of exchange controls. The mobility of capital has led to tax competition, in which sovereign countries lower their tax rates on income earned by foreigners within their borders in order to attract both portfolio and direct investment. Tax competition, in turn, threatens to undermine the individual and corporate income taxes, which remain major sources of revenue (in terms of percentage of total revenue collected) for all modern states.

The response of both developed and developing countries to these developments has been first, to shift the tax burden from (mobile) capital to (less mobile) labor, and second, when further increased taxation of labor becomes politically and economically difficult, to cut government services. Thus, globalization and tax competition lead to a fiscal crisis for countries that wish to continue to provide those government services to their citizens, at the same time 
that demographic factors and the increased income inequality, job insecurity and income volatility that result from globalization render such services more necessary.

This chapter argues that if government service programs are to be maintained in the face of globalization, and if developing countries are to raise the funds needed to achieve the SDGs, it is necessary to cut the intermediate link by limiting tax competition. However, from both practical and normative considerations, any limits set to tax competition should be congruent with maintaining the ability of democratic states to determine the desirable size of their government.

\section{International Tax Competition and the Taxation of Capital}

From its beginnings late in the 19th century, the modern state has been financed primarily by progressive income taxation. The income tax differs from other forms of taxation (such as consumption or social security taxes) in that in theory it includes income from capital in the tax base, even if it is saved and not consumed. Because the rich save more than the poor, a tax that includes income from capital in its base is more progressive (taxes the rich more heavily) than a tax that excludes income from capital (e.g., a consumption tax or a payroll tax). However, the ability to tax saved income from capital (i.e., income not vulnerable to consumption taxes) is impaired if the capital can be shifted overseas to jurisdictions where it escapes taxation.

Two post-1980 developments have dramatically augmented the ability of both individuals and corporations to earn income overseas free of income taxation: The effective end of withholding taxation by developed countries, and the rise of production tax havens in developing countries. ${ }^{4}$ Since the U.S. abolished its withholding tax on interest paid to foreigners in 1984 , no major capital importing country has been able to impose such a tax for fear of driving mobile capital elsewhere (or increasing the cost of capital for domestic borrowers, including the government itself)..$^{5}$ The result is that individuals can generally earn investment income free of host country taxation in any of the world's major economies. ${ }^{6}$ Moreover, even developed countries find it exceedingly difficult to effectively collect the tax on the foreign income of their individual residents in the absence of withholding taxes imposed by host countries, because the investments can be made through tax havens with strong bank secrecy laws. ${ }^{7}$ Developing

\footnotetext{
${ }^{4}$ Reuven S. Avi-Yonah, Globalization, Tax Competition and the Fiscal Crisis of the Welfare State, Harvard Law Review113:1573 (2000) (“Globalization”).

${ }^{5}$ Avi-Yonah, What Goes Around Comes Around: Why the USA is Responsible for Capital Flight (and What It Can Do About It), 13 Haifa L. Rev. 321 (2019); Vito Tanzi, Taxation in an Integrating World (1995); Edward H. Gardner, Taxes on Capital Income: A Survey, in George Kopits (ed.), Tax Harmonization in the European Community (1992). ${ }^{6}$ Reuven S. Avi-Yonah and Linda Z. Swartz, Virtual Taxation: Source Based Taxation in the Age of Derivatives, Derivatives 2:247 (1997); Edmund S. Cohen, Individual International Tax Planning Employing Equity Derivatives, Derivatives 4:52 (1998); Gregory May, Flying on Instruments: Synthetic Investments and Withholding Tax Avoidance, Tax Notes 73:1225 (1996).

${ }^{7}$ Tanzi, supra.
} 
countries, with much weaker tax administrations, find this task almost impossible. Thus, crossborder investment income can largely be earned free of either host or home country taxation. ${ }^{8}$

For example, consider a wealthy Mexican who wishes to earn tax-free interest income from investing in the bonds of an American corporation. All he needs to do is set up, for a nominal fee, a Cayman Islands corporation to hold the bonds. The interest payments are then made to the Caymans corporation without any U.S. tax withheld under the so- called "portfolio interest exemption." (Internal Revenue Code section 871(h)). The individual does not report the income to the Mexican tax authorities, and they have no way of knowing that the Caymans corporation is effectively an "incorporated pocketbook" of the Mexican resident. Nor are the exchange of information provisions of the U.S.-Mexico tax treaty of any help, because the IRS has no way of knowing that the recipient of the interest payments is controlled by a Mexican resident and therefore cannot report this to the Mexican authorities. As a result, the income is earned completely free of tax (the Caymans, of course, impose no income taxes of their own).

When we switch our attention from passive to productive investment, a similar threat to the taxing capacity of both home and host jurisdictions emerges. In the last decade, competition for inbound investment has led an increasing number of countries (123, as of 2018) to offer tax holidays specifically geared to foreign corporate investors. ${ }^{9}$ Given the relative ease with which an integrated multinational can shift production facilities in response to tax rates, such "production tax havens" enable multinationals to derive most of their income abroad free of host country taxation. ${ }^{10}$ Moreover, most developed countries (including the U.S.) do not dare impose current taxation (or sometimes any taxation) on the foreign source business income of their resident multinationals, for fear of reducing the competitiveness of those multinationals against multinationals of other countries. ${ }^{11}$ If they did, new multinationals could be set up as residents of jurisdictions that do not tax such foreign source income. ${ }^{12}$ Thus, business income can also be earned abroad largely free of either host or home country taxation.

\footnotetext{
${ }^{8}$ Chander Kant, Foreign Direct Investment and Capital Flight, Princeton Studies in International Finance 80:1 (1996); Charles E. McLure, Jr., Tax Policies for the 21st Century, Keynote Address to the International Fiscal Association Congress, Geneva (1996); Charles E. McLure, Jr., U.S. Tax Laws and Capital Flight from Latin America, University of Miami Inter-American Law Review 20:321 (1989).

${ }^{9}$ Avi-Yonah, "Hanging Together: A Multilateral Approach to Taxing Multinationals," in Thomas Pogge and Krishen Mehta (eds.), Global Tax Fairness, 113 (2016); Raymond Vernon, In the Hurricane's Eye (1998); United Nations, World Investment Report (1996).

${ }^{10}$ Avi-Yonah, "Hanging Together: A Multilateral Approach to Taxing Multinationals," in Thomas Pogge and Krishen Mehta (eds.), Global Tax Fairness, 113 (2016); James R. Hines, Jr., \& Eric M. Rice, Fiscal Paradise: Foreign Tax Havens and American Business, Quarterly Journal of Economics 109:149 (1994); Rosanne Altshuler and T. Scott Newlon, The Effects of U.S. Tax Policy on the Income Repatriation Patterns of U.S. Multinational Corporations, in Giovannini et al. (eds.), Studies in International Taxation (1993).

${ }^{11}$ Robert J. Peroni, Back to the Future: A Path to Progressive Reform of U.S. International Income Tax Rules, University of Miami Law Review 51:975 (1997).

12 James R. Hines, Jr. The Flight Paths of Migratory Corporations. Journal of Accounting, Auditing and Finance 6:447 (1991).
} 
For example: Intel Corporation, a top 10 multinational, has operations in more than 30 countries around the globe. The company states that "[a]n Intel chip developed at a design center in Oregon, might be manufactured at a wafer fabrication facility in Ireland, packaged and tested in Malaysia, and then sold to a customer in Australia. Another chip might be designed in Japan, fabricated in Israel, packaged and tested in Arizona, and sold in China." ${ }^{13}$ Specifically, outside the United States, Intel has major manufacturing facilities in Puerto Rico, China, Malaysia, the Philippines, Ireland, and Israel. ${ }^{14}$ Thus, outside the United States, all of Intel's manufacturing facilities are located in countries granting tax holidays. Nor does Intel pay current U.S. tax on its income from those foreign operations, because under pre-2017 U.S. law, active income earned by foreign subsidiaries of U.S. multinationals is not taxed until it is repatriated in the form of dividends, which Intel can delay for many years. ${ }^{15}$ Thus, the effective tax rate on Intel's foreign source income is far below the nominal U.S. corporate rate of $21 \%$.

If income from capital can escape the income tax net, the tax becomes in effect a tax on labor. Several empirical studies have in fact suggested that in some developed jurisdictions the effective tax rate on income from capital approaches zero, and tax rates on capital have tended to go down sharply since the early 1980 s (when exchange controls were relaxed). ${ }^{16}$ As a result, countries that used to rely on the revenues from the income tax are forced to increase relatively regressive taxes. The two fastest growing taxes in OECD member countries in recent years have been consumption taxes (from 12\% of total revenues in 1965 to $18 \%$ in 2018) and payroll taxes (from $19 \%$ to $27 \%$ ), both of which are more regressive than the income tax. ${ }^{17}$ Over the same period, the personal and corporate income taxes have not grown as a percentage of total revenues (the personal income tax accounted for $26 \%$ of total revenues in 1965 and $27 \%$ in 2018, while the figures for the corporate income tax are $9 \%$ and $8 \%$ respectively). ${ }^{18}$ The total tax revenue as a percentage of GDP in developed countries went up sharply during the same period (from an average of $28 \%$ in 1965 to almost $40 \%$ in 1994), and this increase is largely accounted for by the rise of consumption and payroll taxes. ${ }^{19}$ Moreover, there is evidence that as the degree of openness of an economy in OECD member countries increases, taxes on capital tend to go down while taxes on labor go up (the income tax is imposed on both capital and labor, so that its stability may mask this trend). ${ }^{20}$

The same trends can be observed in developing countries as well. In non-OECD member countries (outside the Middle East) total government revenues as a share of GDP rose from an

\footnotetext{
${ }^{13}$ www.intel.com/intel/intelis/sites.htm.

${ }^{14}$ Intel, Annual Report (2018).

${ }^{15}$ Reuven S. Avi-Yonah, International Taxation of Electronic Commerce, Tax Law Review 52:507 (1997).

16 Jeffrey Owens and Jacques Sasseville, Emerging Issues in Tax Reform (1997); Dani Rodrik, Has Globalization Gone Too Far? (1997).

${ }^{17}$ Avi-Yonah, Globalization, supra; Owens and Sasseville, supra.

18 Ibid.

${ }^{19}$ World Bank, Tax Policy Handbook (1994).

${ }^{20}$ Enrique G. Mendoza, Assaf Razin \& Linda L. Tesar, Effective Tax Rates in Macroeconomics: Estimates of Tax Rates on Factor Income and Consumption, Journal of Monetary Economics 34:297 (1994); Enrique G. Mendoza, Gian Maria Milesi-Ferretti and Patrick Asea, On the Ineffectiveness of Tax Policy in Altering Long-Run Growth, Centre For Economic Policy Research Discussion Paper 1378 (1996).
} 
average of $18.8 \%$ in $1975-80$ to $20.1 \%$ in $1986-92 .{ }^{21}$ This growth was financed primarily by the growth of revenues from the VAT in the same period (from $25.5 \%$ of total revenues to $31.8 \%$ ). At the same time, revenues from both the individual and the corporate income tax were flat or declined. ${ }^{22}$

A study by Keen and Simone illustrates both the extent of this problem and its impact on developing countries. Keen and Simone show that from 1990 to 2001 corporate tax rates have declined in both developed and developing countries. However, while in developed countries this decline in the rates was matched by a broadening of the tax base, so that no decline in revenues can be observed, in developing countries the same period witnessed a decline of corporate tax revenues by about 20 percent on average. ${ }^{23}$ This decline is particularly important in light of the larger share of tax revenues produced by the corporate tax in developing countries (average 17 percent, as opposed to 7 percent for developed countries). Keen and Simone attribute most of this decline to the spread of targeted tax incentives for MNEs. ${ }^{24}$ From 1990 to 2016 the percent of developing countries granting tax holidays to MNEs grew from 45\% to $58 \%$, and similar trends can be seen for tax breaks for exporters (32\% to $45 \%$ ), reduced corporate rates for MNEs ( $40 \%$ to $60 \%$ ), and free trade zones (17.5\% to $45 \%) .{ }^{25}$ These figures are particularly important because a companion paper by Altshuler and Grubert shows that the evolution of country effective tax rates in the period between 1992 and 1998 seems to have been driven by tax competition, and that US manufacturers are becoming increasingly important in determining location of their investments. ${ }^{26}$

\section{Tax Competition and the Developing Countries}

The drawbacks of tax competition for developed countries are relatively clear, because such countries have an elaborate social insurance safety net that requires a high level of government expenditure and that is threatened by tax competition. ${ }^{27}$ But how does tax competition affect developing countries?

First, it should be pointed out that developing countries need the revenues at least as much as developed countries do, if not more. A common misperception is that only OECD member

\footnotetext{
${ }^{21}$ World Bank, Tax Policy Handbook (1994).

22 Ibid.

${ }^{23}$ Michael Keen and Alejandro Simone, Is Tax Competition Harming Developing Countries More Than Developed? 34 Tax Notes Int'I 1317 (2004); Rachel Griffith and Alexander Klemm, What Has Been the Tax Competition Experience of the Last 20 Years, 34 Tax Notes Int'I 1299 (2004).

${ }^{24}$ Keen and Simone, supra.

${ }^{25}$ Avi-Yonah, Hanging Together, supra; Avi-Yonah, Special Tax Zones and the World Trade Organization, in Antti Laukkanen, Pasquale Pistone and Jan de Goede (eds.), Special Tax Zones in the Era of International Tax Coordination (IBFD, 2019), 127.

${ }^{26}$ Rosanne Altshuler and Harry Grubert, Taxpayer Responses to Competitive Tax Policies and Tax Policy Responses to Competitive Taxpayers: Recent Evidence, 34 Tax Notes Int'I 1349 (2004).

${ }^{27}$ Willi Leibfritz et al., Ageing Populations, Pension Systems and Government Budgets, OECD Economics Department Working Paper 156 (1995).
} 
countries are confronted by a fiscal crisis as a result of the increasing numbers of elderly people in the population. In fact, the increase in dependency ratios (the ratio of the elderly to the working population) is expected to take place in other geographic areas as well, as fertility rates go down and health care improves. ${ }^{28}$ Outside the OECD and the transition economies, the dependency ratio starts in the single digits in the 1990 s, but rises to just below $30 \%$ by $2100 .{ }^{29}$ Moreover, while outside the OECD and the transition economies direct spending on social insurance is much lower, other forms of government spending (e.g., government employment) effectively fulfill a social insurance role. In Latin America, for example, direct government spending on social insurance is much lower than indirect spending through government employment and procurement programs. ${ }^{30}$

Moreover, it seems strange to argue that developing countries need tax revenues less than developed countries because they have less developed social insurance programs. If one accepts the normative case for social insurance, it applies to developing countries with even greater force because of widespread poverty, which means that losing a job can have much direr consequences. ${ }^{31}$ But the need for revenues in developing countries goes far beyond social insurance. In some developing countries revenues are needed to insure the very survival of organized government, as the Russian experience in 1998 demonstrates. ${ }^{32}$ In other, more stable developing countries revenues are needed primarily to provide for adequate education (investment in human capital), which many regard as the key to promoting development. ${ }^{33}$ For example, the UN has estimated that for only an additional \$50 billion per year, all people in the world can obtain basic social services (such as elementary education). ${ }^{34}$ Given current trends in foreign aid, most of these funds have to come from developing country governments, and they are essential if the SDGs are to be reached by $2030 .{ }^{35}$

Second, the standard advice by economists to small open economies is that they should refrain from taxing foreign investors, because such investors cannot be made to bear the burden of any tax imposed by the capital importing country. ${ }^{36}$ Therefore, the tax will necessarily be shifted to less mobile factors in the host country, such as labor and/or land, and it is more efficient to tax those factors directly. But while this argument seems quite valid as applied to portfolio investment, it seems less valid in regard to FDI, for two reasons. First, the standard advice does not apply if a foreign tax credit is available in the home country of the investor, which frequently would be the case for FDI. ${ }^{37}$ Second, the standard advice assumes that the

\footnotetext{
${ }^{28}$ World Bank, supra.

${ }^{29}$ McLure, supra.

${ }^{30}$ K. Subbarao et al., Safety Net Programs and Poverty Reduction: Lessons from Cross-Country Experience (1997).

31 United Nations, Human Development Report (1997).

32 The Economist, Meltdown in Russia (August 29, 1998).

${ }^{33}$ Amartya Sen, Development Thinking at the Beginning of the XXI Century, In Emmerij (ed.), Economic and Social Development in the XXI Century (1997).

${ }^{34}$ United Nations, Human Development Report (1997).

35 United Nations, SDGs, supra.

${ }^{36}$ Assaf Razin and Efraim Sadka, International Tax Competition And Gains from Tax Harmonization, Economics Letters 37:69 (1991).

${ }^{37}$ Timo Viherkentta, Tax Incentives in Developing Countries and International Taxation (1991).
} 
host country is small. However, an extensive literature on multinationals suggests that typically they exist in order to earn economic rents. ${ }^{38}$ In that case, the host country is no longer "small" in the economic sense. That is, there is a reason for the investor to be there and not elsewhere. Therefore, any tax imposed on such rents (as long as it is below $100 \%$ ) will not necessarily drive the investor to leave even if it is unable to shift the burden of the tax to labor or landowners.

This argument clearly holds in the case of rents that are linked to a specific location, such as natural resources or a large market. But what if the rent can be earned in a large number of potential locations ${ }^{39}$ In this case, the host country will not be able to tax the rent if the multinational can credibly threaten to go elsewhere, although once the investment has been made the rent can be taxed. This situation, which is probably the most common, would require coordinated action to enable all host countries to tax the rent earned within their borders. Some possibilities for such action are described below.

This relates to the final argument, which is that host countries need to offer tax incentives to be competitive. An extensive literature has demonstrated that taxes do in fact play a crucial role in determining investment location decisions. ${ }^{40}$ But all of these studies emphasize that the tax incentives are crucial given the availability of such incentives elsewhere. ${ }^{41}$ Thus, it can be argued that given the need for tax revenues, developing countries would in general prefer to refrain from granting tax incentives, if only they could be assured that no other developing country would be able to grant such incentives. ${ }^{42}$

Thus, restricting the ability of developing countries to compete in granting tax incentives does not truly restrict their autonomy or counter their interests. That is the case whenever they grant the incentive only for fear of competition from other developing countries, and would not have granted it but for such fear. Whenever competition from other countries drives the tax incentive, eliminating the competition does not hurt the developing country, and may aid its revenue raising efforts (assuming it can attract investment on other grounds, which is typically the case). Moreover, under the proposals described below, developing countries remain free to lower their tax rates generally (as opposed to granting specific tax relief aimed at foreign investors).

Two additional points need to be made from a developing country perspective. The first concerns the question of tax incidence. Since the tax competition that is most relevant to developing countries concerns the corporate income tax, it is important to attempt to assess

\footnotetext{
38 Jean-Francois Hennart, The Transaction Cost Theory of the Multinational Enterprise, in Pitelis and Sugden (eds.), The Nature of the Transnational Firm (1991).

39 John Dunning, Explaining International Production (1988).

${ }^{40}$ Eric Bond, Tax Holidays and Industry Behavior, Review of Economics and Statistics 63:88 (1981); Michael J. Boskin and William G. Gale, New Results on the Effects on Tax Policy on the International Location of Investment, in Feldtein (ed.), The Effects of Taxation on Capital Accumulation (1987); James R. Hines, Jr. Lessons from Behavioral Responses to International Taxation, National Tax Journal 52:305 (1999).

${ }^{41}$ Stephen E. Guisinger \& Associates, Investment Incentives and Performance Requirements (1985).

${ }^{42}$ Avi-Yonah, Globalization, supra.
} 
the incidence of that tax in evaluating the effects of collecting it on the welfare of the developing country. Unfortunately, after decades of analysis, no consensus exists on the incidence of the corporate tax. While the older studies have tended to conclude that the tax is borne by shareholders or by all capital providers, more recent studies have suggested that the tax is borne to a significant extent by consumers or by labor. ${ }^{43}$ Another possibility is that the tax on established corporations was borne by those who were shareholders at the time the tax was imposed or increased, because thereafter it is capitalized into the price of the shares. It is unlikely that this debate will be decided any time soon (in fact, the incidence may be shifting over time, especially as globalization may enable corporations to shift more of the tax burden to labor). However, from the perspective of a developing country deciding whether to collect taxes from a multinational, three out of the four possible alternatives for incidence (current shareholders or capital providers, old shareholders, and consumers) are largely the residents of other jurisdictions, and therefore from a national welfare perspective the developing country gains by collecting the tax. And even if some of the tax is shifted to labor in the developing country, it can be argued that as a matter of tax administration it is more efficient (as well as more politically acceptable) to collect the tax from the multinational than to attempt to collect it from the workers.

Finally, it should be noted that a developing country may want to collect taxes from multinationals even if in general it believes that the private sector is more efficient is using the resources than the public sector. That is because in the case of a foreign multinational, the taxes that the developing country fails to collect may indeed be used by the private sector, but in another jurisdiction, and therefore not benefit the developing country. One possible solution, which is in fact employed by developing countries, is to refrain from taxing multinationals while they re-invest domestically, but tax them upon remittance of the profits abroad. However, such taxation of dividends and other forms of remittance is subject to the same tax competition problem that we discussed above. Thus, it would appear that overcoming the tax competition problem is in most cases in the interest of developing countries, and the question remains how to do so in the face of the collective action problem described above.

\section{What Can Be Done About Tax Competition?}

The financial crisis of 2008-2009 and the Great Recession that followed led to millions losing their jobs and their homes, and frequently their families as well. Moreover, in Europe the governments reacted to the pressure on the Eurozone by imposing austerity and sharply cutting the social safety net. While the Obama Administration made no such cuts, and the Affordable Care Act was a meaningful move toward bolstering the safety net, the size of the US fiscal stimulus was too limited, and while the banks were saved millions of Americans suffered a decade of low growth and unemployment. ${ }^{44}$

\footnotetext{
43 Joseph A. Pechman, Federal Tax Policy (1987); U.S. Treasury, Integration of the Individual and Corporate Tax Systems: Taxing Business Income Once (1992).

${ }^{44}$ Reuven Avi-Yonah and Orli Avi-Yonah, Be Careful What You Wish For: Reducing Inequality in the $21^{\text {st }}$ Century, 116 Mich.L. Rev. 1001 (2018).
} 
The political reaction on both sides of the Atlantic was dramatic. It led directly to Brexit, the election of Donald Trump in the US and of other right-wing populists in the EU, and the prospect of serious limits to globalization in the form of immigration restrictions, tariffs, and the re-enactment of exchange controls. ${ }^{45}$ The nation state was reasserting itself, and one of the instruments it used was taxation. ${ }^{46}$ In the US the focus on taxation was limited to the first couple of years after the crisis, since the Republican takeover of the House in 2010 meant that no tax measures could be enacted before 2017. But in Europe austerity meant a continued political focus on taxing both the rich and MNEs. In the US, the "Double Irish Dutch Sandwich" was once described in detail in 2010 on the NBC Evening News, but the topic faded thereafter. In Europe, taxes became front-page matter for the whole period after 2008, and this political attention is still ongoing.

The result has been a series of developments that led to a significant enhancement in the ability of the International Tax Regime (ITR) to capture cross-border income.

On the passive income front, a key development was the UBS scandal of 2006-8, which led directly to the enactment of FATCA in 2010. The UBS hearing before the PSI revealed that UBS sent bankers directly to the US to solicit rich individuals to set up shell companies in the Caymans and then reinvest the money through UBS into the US. UBS claimed that even though it was a "qualified intermediary" (QI) and knew who the real owner of the shells was, it was justified under the QI regulations in relying on a form W8BEN that stated that the owner of the income was the Caymans shell and that it was foreign.

The result was the enactment of the Foreign Account Tax Compliance Act (FATCA) in 2010, which imposes a $30 \%$ withholding tax on the US income of any foreign financial institution (FFI) that knows or has reason to know it holds accounts of US residents or citizens and does not reveal such information to the IRS. Because FFIs are frequently prohibited from directly revealing financial information to the IRS, the Obama Administration negotiated over 100 intergovernmental agreements (IGAs) that enable the FFI to turn over the information to its own government, which then exchanges it with the IRS under tax treaties and tax information exchange agreements (TIEAs). Many of the IGAs are reciprocal, so that the US is also obligated (at least on paper) to exchange information about foreign residents.

The IGAs in turn made countries develop a Common Reporting Standard (CRS) for the automatic exchange of financial information, and the OECD then negotiated a Multilateral Agreement on Administrative Cooperation in Tax Matters (MAATM), which relies on the CRS to provide for automatic exchange without the ability to rely on bank secrecy or dual criminality

\footnotetext{
${ }^{45}$ Kim Clausing, Open: The Progressive Case for Free Trade, Immigration, and Global Capital (2019).

${ }^{46}$ European Union, COUNCIL DIRECTIVE (EU) 2016/1164 of 12 July 2016 (ATAD).
} 
provisions. Most countries in the world, and all OECD members except the US have ratified the MAATM.

The result has been that it is much more difficult to evade income taxation now than it was ten years ago. A potential evader has to worry that in almost every country information about her income may be collected and transmitted to her residence jurisdiction. In addition, she has to worry that the information may either be leaked by a whistleblower (as in the Panama Papers) or hacked (as in the Paradise Papers). I would estimate that FATCA alone has led to a significant decrease in the international tax gap in the US, well below my $\$ 50$ billion estimate from $2005 .{ }^{47}$

On the active income front, there have also been dramatic developments in the last decade. The first was the OECD Base Erosion and Profit Shifting (BEPS) project (2013-15), which was led by the $\mathrm{G} 20$ and resulted in fifteen action steps designed to enhance both source and residence based taxation of active income. For example, BEPS Action 2 bars a deduction for payments to hybrid entities, thereby eliminating the impact of check the box.

BEPS was introduced in the EU as the Anti-Tax Avoidance Directive (ATAD), which generally came into effect in January 2019 and which among other measures requires all EU members to adopt strict CFC rules (e.g., generally requiring residence-based taxation if the effective tax rate of the source jurisdiction is below $50 \%$ of the tax rate in the residence jurisdiction). This measure, in addition to the enactment of BEPS Action 2 means that it is much harder now to shift profits artificially out of EU member states. Another important measure in BEPS and ATAD is the primary purpose test (PPT), which requires that all tax treaties incorporate language that the treaty will not apply to transactions if a primary purpose of the transaction was tax avoidance.

Until 2017, it could be argued that the US was a laggard in terms of combating tax avoidance, because it took the position that it was already compliant with BEPS, rejected the PPT, and did not sign the MAATM. But the 2017 tax reform (TCJA) dramatically changed that. TCJA includes three measures that significantly increase taxation of US-based as well as foreign-based MNEs. First, TCJA imposed a one time, hefty transition tax on the $\$ 3$ trillion of past, accumulated earnings of US-based MNEs. Second, while TCJA provided for an exemption for certain future dividends from CFCs to their US parents, this exemption is strictly limited to a deemed $10 \%$ return on tangible property, which for most US-based MNEs is close to zero (because they rely heavily on intangibles). For any amount that exceeds this deemed return, TCJA imposes a current minimum tax of $10.5 \%$ (13.25\% if foreign tax credits are included) on worldwide earnings of the MNE. Third, TCJA imposes an alternative minimum tax of $10 \%$ on both US- and foreign based MNEs by disregarding interest, royalty and some other payments from the US to the related foreign entity.

\footnotetext{
47 Reuven Avi-Yonah and Gianluca Mazzoni, BEPS, ATAP and the New Tax Dialogue: A Transatlantic Competition? 46 Intertax 885 (2018).
} 
The result of these developments (BEPS, ATAP ad TCJA) is that both US and foreign MNEs are likely to be subject to significantly higher levels of tax on cross-border active income than they were before $2008 .{ }^{48}$

To give an example: The structure used by most US-based MNEs before 2017 for their foreign operations was to have a top level CFC in a low-tax jurisdiction, with lower-tier CFCs in high tax jurisdiction. The parent would transfer intellectual property to the top CFC via a cost sharing agreement, and the top CFC would in turn would license the IP to the lower-tier CFCs. The key to this structure was that under check the box, only the top CFC would be treated as a corporation, while all the lower CFCs would be disregarded (i.e., treated as branches of the top CFC). As a result, while for foreign tax purposes deductible royalties from the lower CFCs to the top CFC would be effective in shifting profits to the low-tax jurisdiction of the top CFC (and not subject to withholding under treaties), for US tax purposes these royalties did not exist and so did not trigger a deemed dividend to the US parent. In addition, deductible cost sharing payments could be made from the US parent to the top CFC.

This structure does not work any more, for three reasons. First, under BEPS Action 2, as implemented by the EU ATAP, the royalties from the bottom CFCs to the top CFC would not be deductible because they are to a hybrid entity. Second, the cost sharing payments from the US parent to the top CFC would be subject to the BEAT minimum tax. And finally, the top CFC as well as all the disregarded entities below it would be subject to the GILTI minimum tax $(10.5 \%$ or $13.25 \%$ with foreign tax credits) on a current basis. The result is that US-based MNEs need to restructure their foreign operations and are likely to be subject to a significantly higher worldwide effective tax rate than before 2018, despite the fact that both check the box and IRC section $954(c)(6)$ have not been affected by the TCJA. ${ }^{49}$

\section{Conclusion}

In 2000, I predicted that unless something was done about limiting tax competition, there would be a retreat from globalization and a revival of nationalism. ${ }^{50}$ This has now happened, in the form of restrictions on immigration and renewed tariffs and exchange controls. Increased nationalism could even lead to a new world war.

The last decade has seen significant limits to tax competition. But in order to prevent further political damage, more needs to be done. First, additional changes to bolster the ITR are required. Second, the added revenues should be used to bolster the social safety net and prevent another Great Depression. This is particularly true given the economic impact of the coronavirus pandemic.

\footnotetext{
${ }^{48}$ Kim Clausing, Profit Shifting Before and After the Tax Cuts and Jobs Act (2019).

${ }^{49}$ Avi-Yonah and Mazzoni, supra; Avi-Yonah, "Evaluating BEPS," in Sergio Andre Rocha and Allison Christians (ed.), Tax Sovereignty in the BEPS Era (Kluwer, 2017), 97.

${ }^{50}$ Avi-Yonah, Globalization.
} 
There are three additional measures that I believe would strengthen the ITR.

1. In regard to passive income, despite CRS and MAATM, I do not think the solution can depend entirely on exchange of information and residence based taxation. There are too many residence countries to cooperate effectively, and there will always be some non-cooperative tax havens to attract evaders. But the key point is that portfolio investments are limited to a small number of large jurisdictions. If the US, EU and Japan could cooperate to re-institute withholding taxes on interest, a large part of the problem could be resolved.

2. In regard to active income, there are a limited number of residence countries of MNEs (over 90 of the Fortune 100 are resident in the G20). If all the $\mathrm{G} 20$ could agree to further strengthen CFC rules to eliminate exemption or deferral, most MNE income would be taxed currently. In the US this would mean that the GILTI provision should be revised to eliminate the $10 \%$ deemed return exemption and increase the rate to $21 \%$. Strict anti-inversion rules (e.g., a managed and controlled residency test) would eliminate the ability of MNEs to artificially move out of the US.

3. Since active income should be taxed at source, and since tax competition does not affect the market jurisdiction, the EU proposals for eliminating the PE standard and substituting a virtual PE threshold for "significant digital presence" should be adopted. In addition, a formula should be used to allocate residual profits under the arm's length standard between source jurisdictions. ${ }^{51}$ These ideas were both broached by the OECD and are likely to be adopted soon. The key issue is that the US and other G20 countries should grant foreign tax credits to such taxes. The fact that most G20 countries have similar tax rates should make such FTCs acceptable.

If we want to narrow the North-South divide that threatens our world, some limits on tax competition are inevitable. The world faces a crucial choice in the 2020s. We can either continue retreating from globalization in favor of xenophobic nationalism, tariffs, immigration restrictions, and exchange controls. That road leads ultimately to war, as it did in the 1930s. Or we can revive globalization by investing in a robust social safety net, infrastructure, education, and job creation. While more needs to be done, we have made significant progress in curbing tax competition in the last decade. The key move now is to take the added revenue and spend it wisely.

\footnotetext{
${ }^{51}$ Avi-Yonah, "A Proposal for Unitary Taxation and Formulary Apportionment (UT+FA) to Tax Multinational Enterprises," in Peter Dietsch and Thomas Rixen (eds.), Global Tax Governance, 289 (2016).
} 